\title{
MDM4 Gene
}

National Cancer Institute

\section{Source}

National Cancer Institute. MDM4 Gene. NCI Thesaurus. Code C88218.

This gene plays a role in both cell cycle arrest and the inhibition of apoptosis. 